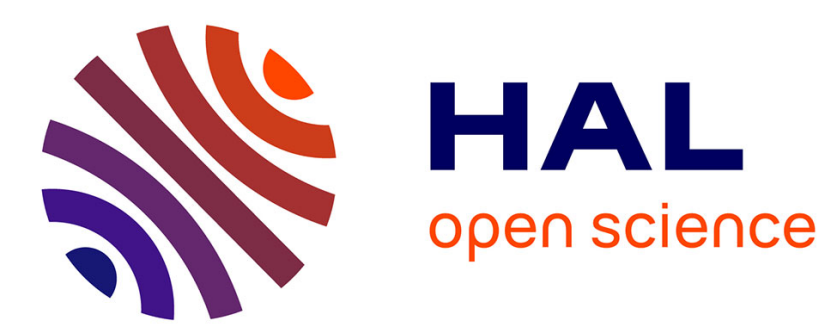

\title{
Wideband measurements and analysis of propagation losses within a building
}

\author{
Gheorghe Zaharia, Ghais El Zein, Jacques Citerne
}

\section{To cite this version:}

Gheorghe Zaharia, Ghais El Zein, Jacques Citerne. Wideband measurements and analysis of propagation losses within a building. IEEE-APS International Symposium, Chicago, 1992, Jul 1992, Chicago, United States. pp.1380-1383, 10.1109/APS.1992.221639 . hal-00875601

\section{HAL Id: hal-00875601 https://hal.science/hal-00875601}

Submitted on 5 Nov 2013

HAL is a multi-disciplinary open access archive for the deposit and dissemination of scientific research documents, whether they are published or not. The documents may come from teaching and research institutions in France or abroad, or from public or private research centers.
L'archive ouverte pluridisciplinaire HAL, est destinée au dépôt et à la diffusion de documents scientifiques de niveau recherche, publiés ou non, émanant des établissements d'enseignement et de recherche français ou étrangers, des laboratoires publics ou privés. 


\title{
WIDEBAND MEASUREMENTS AND ANALYSIS OF PROPAGATTON LOSSES WTTHIN A BUILDING
}

\author{
GH ZAHARLA*, G. EL ZEIN and J. CIJERNE \\ Laboraloire Composants ef Systentos pour Tél6oommunications \\ URA 834, INSA, 35043 RENNES, FRANCE
}

\begin{abstract}
An simplified setup using an HP network analyzer to perfonth path loss measurements for the landoor tath channel in the $0.8-1 \mathrm{GHz}$ bend is described. In order to analyse the frequency selectivity of the channel, two new postprocessing dart methods are proposed. A comparison with another published method is also presented.
\end{abstract}

\section{INTRONUCTLON}

Indoor radio propagation has been ar active area of study in recent yegrs, with several reporting wideband lompulse tesponse measwemens. Rartio propagation studies can be performed ejther is the time domain or in the frequency domis. 'The advantages of the frequency domain measurements were pointed out in Refereace [1]. However, there is another advantage that has not yet been osed: the possibility to analyse the selectivity of the transmission channel. This paper describes a simplified version of the conflguration Initielly proposed by Pahlaran and Howard [1] and also improved by Zaghloul, Morrisson and Fatouche [3]. Though the setup proposed here is similar to that of Zaghloul et al, the method of operstion and unilyses presents sone particulanities.

\section{MEASUREMENT SETUP}

The main component of the measurement system is an $\mathrm{HP} 8753 \mathrm{C}$ network analyzer with an $\mathrm{HP} 85046 \mathrm{~A}$ \$-partureter kit that outputs a swept frequency signal and analyses the recetved signal. The signal generated by the nefwork analyzer is propagated by a $\lambda / 4$ onnidirectional antenna with a gain $G=0 \mathrm{dBi}$. The output of the nerwork analyzer is connected to the transmiting antenna through a $50 \mathrm{~m}$ cosxial cable with $8 \mathrm{~dB}$ attentuation at $0.9 \mathrm{GHz}$. The signal from the sirmilary receiver enterna is renumed through a $4.5 \mathrm{~m}$ coaxial cuble to the nerwork analyzer to detemine $S_{2 L}$. The transnutting and receiving antennas are wideband units with groundplare, plared at $1.5 \mathrm{~mL}$.

Conceming the time invarinnet of the chanpel, the messurements were collected during the summer hollidays, wher all the uniwessitary campus of INSA-Rennes was deserted. No other researchers were in the LCST laboratory. The surfounding environment was also kept stationary by preventing movements. This allows us to assume that the channel was time ifvariant duning the measurements.

In order to reduce the influence of the noise, for each position of the transmitting antenna, four measurements were performed and the results were avernged.

The ealibration of this instrumentation was performod out the $50 \mathrm{mr}$ coaxial cable. So, the measured channel is represented by the building and the two antengs with their coakial cubles. 


\section{DESCRIPTION OF 'THE MEASUREMENTS}

The measurements were spatially distributed throughout the lest area (the ground flour of the LCST laboratory) by fixing the receiving artennis in a comer of a laboratory and moving the itansonitting antenna to different Iocations. During the measurements, the both antennes were kept fixed.

The measurements consist of 801 values for $\left|S_{21}\right|$ at a frequency spacing of $0.25 \mathrm{MHz}$ for a frequency span of $200 \mathrm{MHz}$, which is centered at $0.9 \mathrm{GHz}$. The magnitude of $S_{21}$ is obtained in LOGM format and represents the powtr loss of the channel. For each location were obtained 801 magnitude values. The pourer of the signal generated by the network analyzer is $+20 \mathrm{dBm}$ (the maximil value) and the sweep time for the four measurethents is 650 ms.

\section{MEASIIREMENT ANALYSIS}

The main objective of this measurements is to determine the radio coversge, that is related to the power-distance relationship in the area.

A. Averaged power lass wersis distance; For a fixed trangritter power and a fixed frequency, the power loss (P) incresses with dislance (d) between antennar: as:

$$
P(f, d)=A(\rho) d f(f)
$$

where $\alpha(f)$ is the exponent of the power-distance relationship and $A(f)$ is the power loss for $\mathrm{d}=1 \mathrm{~m}$. In Reference [1], is simple analysis is deseribed, using averaged values for $P(f, d)$ :

when:

$$
P(d)=E[P(f, d)]=\frac{1}{B 01} \sum_{i=1}^{801} P(f, d)
$$

$$
f i=800+(i-1) 0.25[M H z], \quad 1 \leq i \leq 801
$$

As in Reference [1] sesuming that:

$$
P(d)=A d x
$$

when the logarithm of (4) is twen, the linear relationship:

$$
10 \log t 0[P(d)]=10 \log 10(A)+\alpha[10 \log 10(d)]
$$

berween powrer loss in $\mathrm{dB}$ and 10 logio of the distance results. Using a linear regression analysis [4], the migimum mean square error (MMSE) line is calculated for the dependence of power loss (dB) on 10 logio of the distance. The slope of the regression line gives the experimental value o at

The lines regression analysis gives $\alpha=1.925$ and $A=36.7 \mathrm{~dB}$. The stendard deviation of the average power losses from the regressian estimates is ems a $2.35 \mathrm{~dB}$. The correlation coefficient $\pi=0.933$ friticates that increasing power loss is highly correlated with incressing distance.

B. Power loss versus distance for each frequency; The results presented showe represent global values. When the logurithm of (1) is taken, the relationship:

$$
10 \log 10[P(f, d)]=10 \log 10[A(f)]+a(f)[10 \log 10(d)]
$$




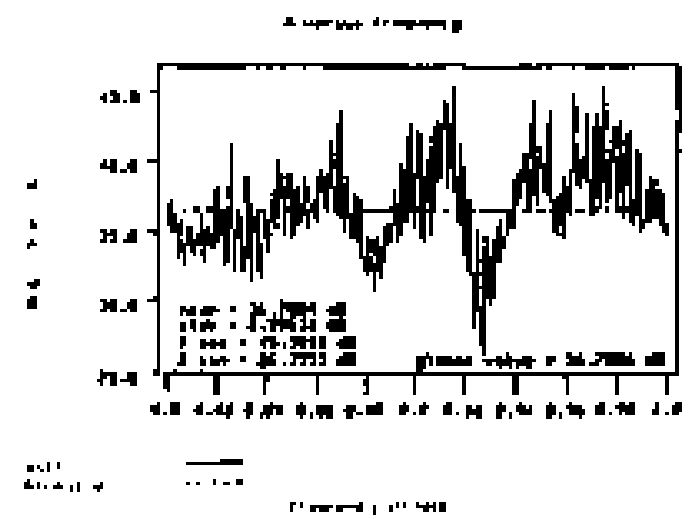

a)

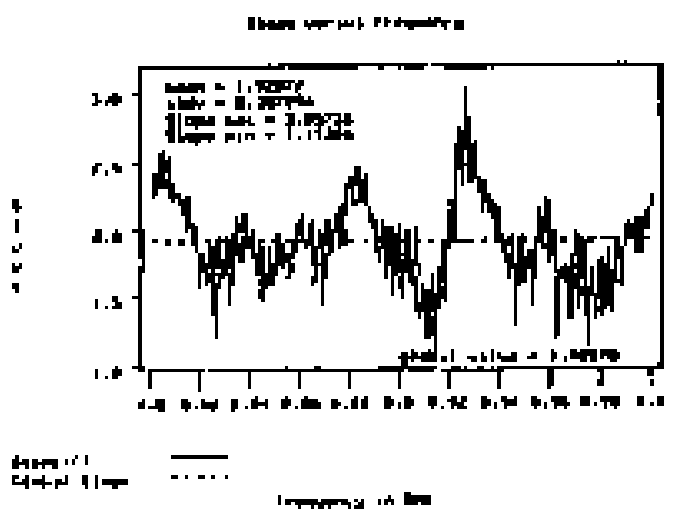

b)

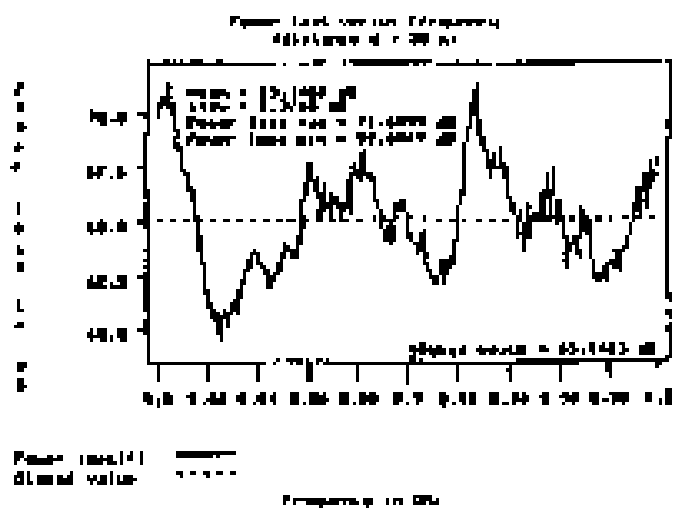

c)

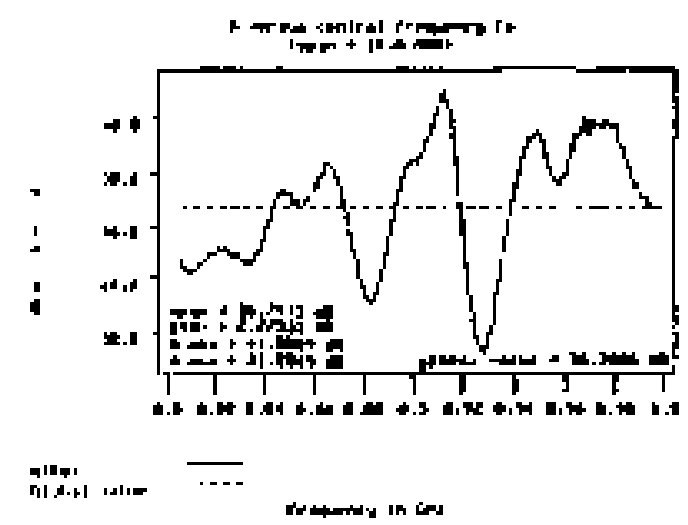

d)

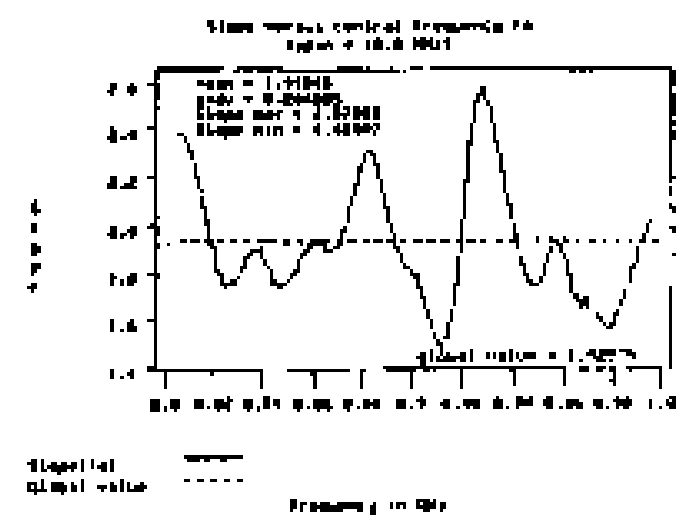

e)

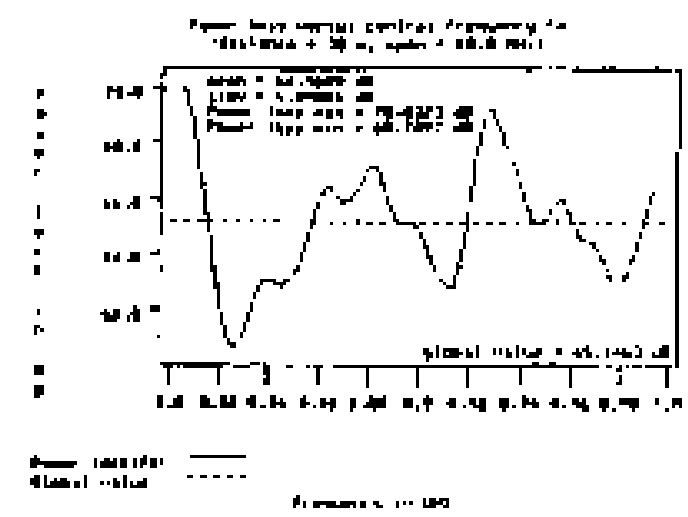

)

Fit. 1. a,b) and c); whthod B; d),e) and b: method $C$.

results. Now, the linew regrestion analysts car be performed for each Erequency. From this analysis, BO1 values for $A$ and a are obtained. Fig. $\mathrm{l}$ ) and $b$ ) show a plol of $A(f)$ and $a(f)$ versus frequency. The global values obtained above are also shown. Some impontant conclusions cas be poirled Out:

I) the chinnel presents a consideruble froquency selectivity;

2) the awertges of the 801 samples for $A(D)$ and a(f) respecrively are equal to the global ralues obtatind above this observation may be 
mathematically proved). Therefore, this analysis is more general: the results obtained at paragraph A. may be deduced trom paragraph B. by simple avoriping:

3) using $A(0$ and cu( () , relation (6) allows the comfoutation of the power loss in (AB versus frequency for a fixed distance. Fig 1 c) shows a plot of the power loss versus frequence for $d=30 \mathrm{~m}$.

It fs obvious that this result is more oseful: for $\mathrm{f}=825 \mathrm{MLH}$ (for

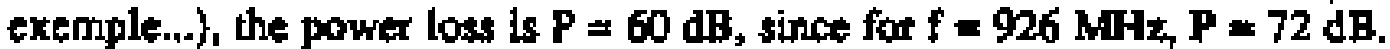
For a given communication system with a $10 \mathrm{MHz}$ frequency band, it is more convetivent to choose the band $825 \mathrm{MHz}$ - $835 \mathrm{MHz}$ than the band $925 \mathrm{MHz}$ $935 \mathrm{MHz}$ th other wonds, the radio coverage depondis on the choosod band.

C. Power lass versur dirtance for a given frequency band. Assuming

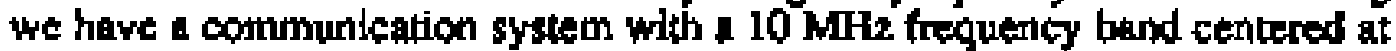
$f_{0}$, the problem is to obtatn the ratio coverage, in other wouls to obtain a plot of the power loss versus fo for a given disbnes. For this exemple, we have

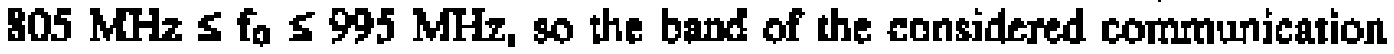
system is $\mathrm{b}=\left[\mathrm{f}_{\mathrm{o}}-\$ \mathrm{MHz}, \mathrm{f}_{\mathrm{g}}+5 \mathrm{MHz}\right]$. For a grven $\mathrm{f}_{\mathrm{o}}$, we thay use the firsttype analyqis: for the 41 powct lose valus contgined in the frocuency band $b$. the average value may be computed:

$$
P(d)=\frac{1}{41} \sum_{j=1}^{41} P\left(f_{b} d\right)
$$

Then, the linent repessiot unalysis berwen $P(d)$ and $d$ gives $A$ and $a$ for the frequenty to. Using this regression aralysis for alt possible values of

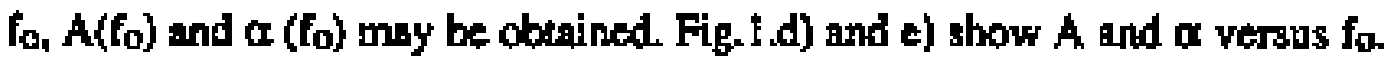
In tact, the results represent a smoothing of the curves presented in Fie.l.aj) and b). So, it is not nocessary to repeat 761 tioes the regressive anglysis, Thet, using (6) for $d=30 \mathrm{~m}$ and $f=f_{0,}$ the power loss may be obthined. The result showil in Fig. 1.f) is a smoothing of the curve presented in Fig.1.c). applicationg.

It seems that the results of the method $C$ are rrore useful for proctical

\section{CONCLLISLON}

This paper presents a simplified sepap to toessure wideband path loss of indoor radio channels. Two new postprocessing methods were destribed. Wethod B is the most general: it may be used to obtain the resuls of the other nethods, in phaticplar the boults presterted bef Refehce [1,2].

\section{REFERENCES}

[l] HOWARD, S.J. and PAHLAVAN, K: "Measurement and andysis of the indoor ratio channel to the frequency domain", IEEE Trans", 1990, IM - 39, pp, 751-755

[2) PAHLAYAN, $\mathbf{K}$, and HOWARD, S.J.: "Frequency domain measurements of indow radio channel ${ }^{m}$, Electron.Lett., 1989, 25, pp. 1645 1647

[3] ZAGHLOUL, $K$, MORRISON, $G$., and FATOUCHE, M.: "Frequency response and path loss measurements of the indoct channed", Electron. Lett., 1991, 27, (12), pp. 1021 - 1022

[4] URKOWTTZ, H.: "Signal theory and random processes", Artech Hause Inc., Wastington, $1983,6.7$ 